\title{
PROBLEMATIKA PENERAPAN METODOLOGI BARAT PADA PENDIDIKAN DASAR DALAM PERSPEKTIF ISLAM
}

\section{Muhamad Parhan ${ }^{1}$ Adilla Tieky I. D. ${ }^{2}$, Ajeng Irma H. S. ${ }^{3}$, Arnis Susnita ${ }^{4}$, dan Eva Fauziah K.5}

\author{
Muhamad Parhan, Universitas Pendidikan Indonesia, Bandung \\ e-mail: parhan.muhamad@upi.edu \\ Adilla Tieky I. D, Universitas Pendidikan Indonesia, Bandung \\ e-mail: tiekyadilla@upi.edu \\ Ajeng Irma H. S, Universitas Pendidikan Indonesia, Bandung \\ e-mail: ajengirma@gmail.com \\ Arnis Susnita, Universitas Pendidikan Indonesia, Bandung \\ e-mail: arnissusnita17@gmail.com \\ Eva Fauziah K, Universitas Pendidikan Indonesia, Bandung \\ e-mail: evafau@gmail.com
}

\begin{abstract}
Abstrak
Penelitian ini merupakan sebuah upaya yang dilakukan peneliti dalam mengkaji tentang masalah-masalah penerapan metodologi Barat pada pendidikan dasar di Indonesia dalam perspektif Islam. Upaya yang dilakukan dengan cara studi pustaka yang bertujuan untuk mendapatkan metode pendidikan yang tepat dan sesuai dengan tujuan pendidikan di Indonesia. Pendekatan penelitian ini merupakan kombinasi antara penelitian kuantitatif dan kualitatif (mix research) dengan teknik pengumpulan data berupa sebar kuesioner, studi pustaka, dan wawancara yang dilakukan kepada beberapa narasumber yang berbeda guna mendapatkan jawaban-jawaban untuk disimpulkan dengan benar. Penelitian ini dapat dilihat dari hasil kuesioner dan wawancara. Masalah-masalah penerapan metodologi Barat pada pendidikan dasar di Indonesia dapat diatasi dengan menerapkan beberapa cara mendidik anak yang dicontohkan oleh Rasulullah saw., yaitu didasarkan kepada Alquran dan Hadits, serta mengambil metodologi Barat dengan terlebih dahulu melakukan pemilihan konten yang tepat dan relevan dengan pendidikan Islam.
\end{abstract}

Kata Kunci: problematika, metodologi barat, pendidikan dasar

\begin{abstract}
This research is an attempt by the researcher in examining the problems of applying Western methodology to basic education in Indonesia in an Islamic perspective. Efforts are made by means of literature study that aims to get the right educational methods and in accordance with the objectives of education in Indonesia. This research approach is a combination of quantitative and qualitative research (mix research) with data collection techniques in the form of questionnaires, literature studies, and interviews conducted to several different sources to get answers to be concluded correctly. This research can be seen from the results of the questionnaire and interview.
\end{abstract}




\section{AL- ADABIYAH: Jurnal Pendidikan Agama Islam}

The problems of applying Western methodology to basic education in Indonesia can be overcome by applying several ways of educating children as exemplified by the Messenger of Allah, which is based on the Qur'an and Hadith, and taking Western methodologies by first selecting the right content and relevant to Islamic education

Keywords: problematics, western methodology, primary education

\section{PENDAHULUAN}

Manusia sejatinya dapat dan harus dididik sesuai kodratnya sebagai makhluk ciptaan Allah Swt. yang hidup bermasyarakat karena memiliki kemampuan tumbuh dan berkembang. Pendidikan menjadi hal yang harus ditempuh oleh setiap manusia. Indonesia memiliki tujuan pendidikan nasional, yaitu mengembangkan potensi peserta didik agar menjadi manusia yang beriman dan bertakwa kepada Tuhan Yang Maha Esa, berakhlak mulia, sehat, berilmu, cakap, kreatif, mandiri, dan menjadi warga negara yang demokratis serta bertanggung jawab (Undang-Undang Nomor 20 Tahun 2003 Tentang Sistem Pendidikan Nasional Pasal 3).

Sebagaimana yang sudah dinyatakan dalam UU No. 20 Tahun 2003 Pasal 3 Tentang Tujuan Pendidikan Nasional, Indonesia bercita-cita agar mampu membuat manusianya beriman kepada Tuhan Yang Maha Esa, di mana jika telah tercapai tujuan tersebut akhlak mulia, kreativitas, kemandirian, dan kesadaran diri akan tercapai. Karena tidaklah seseorang akan menimbulkan masalah atau memiliki sikap egosentris yang tinggi jika kehidupannya dipenuhi dengan keimanan yang tinggi. Namun sayang cita-cita tersebut hingga saat ini belum tercapai, peserta didik hanya dibuat seolah-olah belajar dengan buku-buku dan rancangan pembelajaran yang sedemikian rupa agar mampu menjawab soal-soal ujian dan mencapai standar kompetensi untuk akhirnya membuat peserta didik tersebut lulus dengan standar yang terus berubah-ubah. Banyak penelitian mengenai pendidikan yang terus digali, mendapatkan banyak indikator yang memengaruhi kurangnya kebermaknaan pendidikan Indonesia. Menurut Ahmad Tafsil dalam Ismail (2018) ada 6 faktor yang membuat pendidikan Indonesia tertinggal, yakni: (1) sistem pendidikan yang kaku, (2) sistem pendidikan nasional kita telah diracuni dengan praktik korupsi, kolusi dan nepotisme, (3) sistem pendidikan kita tidak berorientasi pada pemberdayaan masyarakat, (4) sistem pendidikan kita belum mengantisipasi abad ke-21, (5) biaya atau anggaran pendidikan masih terlalu kecil, dan (6) daya saing lulusan yang masih rendah. 


\section{AL- ADABIYAH: Jurnal Pendidikan Agama Islam}

Berfokus pada indikator pertama, Indonesia sangatlah sibuk dengan penilaian yang sesuai dengan sistem, terpusat pada pengukuran kognitif walaupun banyak propaganda penilaian afektif adalah yang utama, namun tetap saja pada akhirnya pendidikan Indonesia tidak bisa keluar dari belenggu penilaian konkret yang dapat didokumentasikan melalui angka-angka. Hal tersebut tentu jelas tidak mampu memenuhi harapan atau cita-cita dari tujuan pendidikan nasional, ditambah dengan fakta dan evaluasi internasional pendidikan Indonesia yang mengecewakan seperti yang dipublikasikan oleh Programme for International Student Assesment (PISA) pada tahun 2018 dengan pembagian skor tinggi, menengah, dan rendah. Negara yang paling tinggi skornya adalah Cina dengan skor 578.7, negara yang berada di tengah pemeringkatan sejumlah 23 negara, yakni Australia (499.0) - Greece (453.3) dan letak peringkat negara paling bawah, yakni Dominican Republic dengan skor 334.3 yang mendapati peringkat ke-77, Indonesia sendiri hanya terpaut 6 negara, yakni peringkat ke-71 dengan skor 382.0.

Dengan data di atas membuktikan pendidikan Indonesia belum berhasil, dengan sistem, kurikulum, dan metode pengajaran yang begitu banyak diterapkan seperti jigsaw dan inquiry, membuat pembelajaran dengan stimulus -respons, reward dan lain sebagainya tidak mampu membuat peserta didik terpicu atau semakin tertarik membaca dan mengkaji suatu ilmu yang nantinya menjadi sebuah keahlian yang mereka miliki.

Banyak metode pendidikan yang kurang bermakna bagi anak, yang dibuktikan dengan kurangnya penerapan materi pembelajaran dalam kehidupan sehari-hari sehingga lebih mengedepankan pengetahuan dalam konteks pembelajaran tanpa diterapkan dalam kehidupan nyata (Parhan, M. \& Sutedja, 2019). Guru harus memperhatikan metode dalam mendidik agar tujuan pendidikan dapat dicapai sesuai harapan, maka dari itu metode pendidikan disesuaikan dengan tahap perkembangan peserta didik. Umumnya di usia sekolah dasar kelas awal, yaitu kelas 1-3 lebih menyukai materi dalam bentuk permainan, senang bergerak, dan senang praktik langsung (E. Burhaein, 2017). Berdasarkan latar belakang di atas peneliti akan mengkaji tentang masalah-masalah penerapan metodologi barat pada pendidikan dasar di Indonesia dalam sudut pandang agama Islam.

\section{METODE PENELITIAN}

Pendekatan penelitian ini menggunakan kombinasi antara penelitian kuantitatif dan kualitatif. Pendekatan kuantitatif digunakan untuk menghitung 


\section{AL- ADABIYAH: Jurnal Pendidikan Agama Islam}

hasil kuesioner yang sudah disiapkan dengan menggunakan perhitungan statistik yang dapat diukur dan dapat disajikan dalam bentuk sebuah angka dan diagram sehingga dapat dilihat secara langsung.

Sementara itu pendekatan kualitatif dilakukan dengan teknik wawancara terhadap narasumber. Setelah itu, hasil wawancara tersebut digunakan untuk memperkuat pendapat agar bisa menjabarkan dan menganalisis permasalahan yang terjadi dalam metodologi barat yang diterapkan di pendidikan dasar di Indonesia dalam pandangan Islam. Hal ini dilakukan dengan mendeskripsikan hasil analisis dalam bentuk kata-kata dan bahasa yang disusun dengan cara deskripsi-analitik, yaitu mengumpulkan data dengan menggambarkan keadaan yang sebenarnya dari penelitian yang dilakukan tersebut, kemudian disajikan dalam bentuk naratif dan dianalisis.

Teknik mengumpulkan data dalam penelitian ini berupa sebar kuesioner, studi pustaka, dan wawancara. Wawancara dilakukan kepada beberapa narasumber yang berbeda sehingga dapat menghasilkan beberapa jawaban untuk disimpulkan dengan benar dan akurat.

Untuk menganalisis data kuantitatif, peneliti menggunakan statistika dan untuk data kualitatif peneliti menganalisis permasalahan-permasalahan dalam penerapan metodologi barat di sekolah dasar dalam pandangan Islam.

Penelitian ini mencakup wilayah Universitas Pendidikan Indonesia dan universitas lain. Cakupan wilayah ini dipilih karena untuk menunjang kesesuaian dengan narasumber dan responden yang bisa memberikan pendapat terhadap permasalahan yang ingin diangkat oleh peneliti sehingga dapat membuktikan permasalahan yang ada di dunia pendidikan dasar saat ini dalam pandangan Islam.

\section{HASIL PENELITIAN DAN PEMBAHASAN}

Pendidikan merupakan perantara untuk mendapatkan pengetahuan, urgensi pendidikan dalam sebuah negara sudah tidak bisa diragukan lagi, maka dari itu pendidikan tidak bisa diselenggarakan tanpa landasan atau pandangan dan tanpa rencana yang serius. Negara Kesatuan Republik Indonesia merupakan salah satu negara yang serius dalam mengurusi pendidikan seperti yang dicita-citakan dalam Pembukaan UUD 1945 alinea keempat, yakni "Mencerdaskan kehidupan bangsa", hal ini membuat Indonesia merumuskan peraturan lainnya tentang pendidikan. 


\section{AL- ADABIYAH: Jurnal Pendidikan Agama Islam}

Landasan pendidikan di Indonesia bersumber pada Pancasila, yang isi kurikulumnya (dalam Rasyidin dkk., 2017) memperhatikan hal-hal berikut.

1. Peningkatan iman dan takwa

2. Peningkatan akhlak mulia

3. Peningkatan potensi, kecerdasan, dan minat peserta didik

4. Keragaman potensi daerah dan lingkungan

5. Tuntutan pembangunan daerah dan nasional

6. Tuntutan dunia kerja

7. Perkembangan ilmu pengetahuan, teknologi, dan seni

8. Agama

9. Dinamika perkembangan global

10. Persatuan nasional dan nilai-nilai kebangsaan

Dari hasil penelitian yang dilakukan melalui kuesioner, 50 responden yang terdiri dari mahasiswa Universitas Pendidikan Indonesia, aktifis masjid dan organisasi kepelajaran, menyatakan jika menerapkan metodologi pendidikan Islam akan berdampak postif.

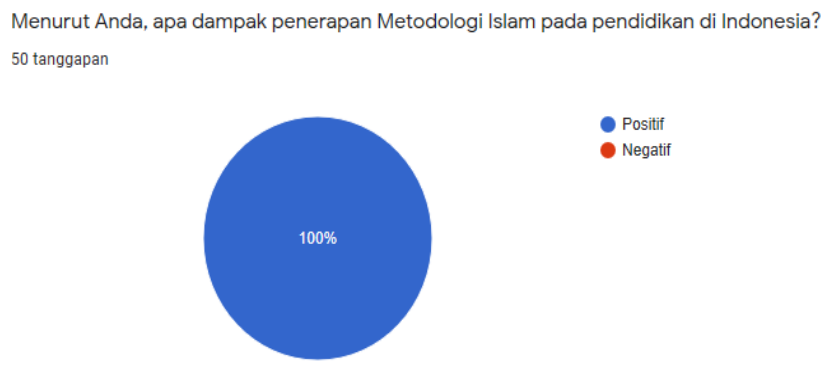

Gambar 1. Diagram dampak penerapan metodologi pendidikan Islam

Hal di atas menunjukkan keyakinan muslim Indonesia akan pendidikan yang Islami, walau $24 \%$ tidak mengetahui seperti apa metodologi pendidikan Islam itu sendiri. 


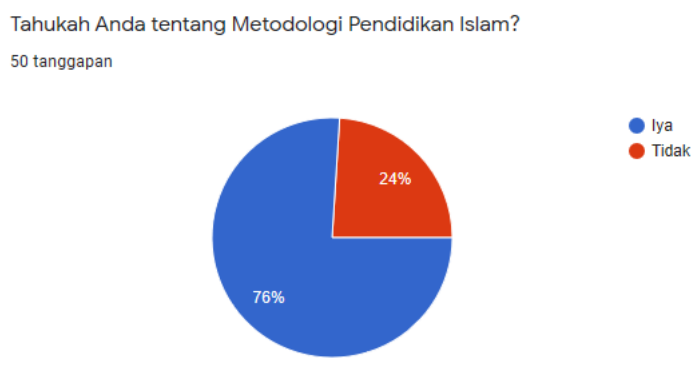

Gambar 2. Diagram pengetahuan tentang metodologi pendidikan Islam

Adapun kesalahan metodologi pendidikan barat menurut pandangan muslim terdapat beberapa yang terjadi terhadap pendidikan yang ada di Indonesia. Misalnya dalam penerapannya, metodologi barat tidak menerapkan nilai-nilai agama sehingga menjauhkan manusia dari tabiat (fitrah) menjadi tidak mengenal Tuhannya. Selain itu, metodologi barat tidak dilandasi dengan adab (akhlak) yang baik sehingga tidak ada nilai moral di dalamnya. Kemudian para pendidik dalam menerapkan metodologi barat tidak menyaring secara menyeluruh apa yang akan disampaikan kepada peserta didik. Suyitno (2020) selaku dosen Universitas Pendidikan Indonesia, Fakultas Ilmu Pendidikan, Prodi PGSD menyatakan bahwa: Metodologi pendidikan Barat tidak mendekatkan manusia kepada Sang Pencipta, yakni Allah Swt. dan metodologi Barat ini tidak bersumber dari wahyu. Metodologi barat juga banyak yang bertentangan dengan nilai-nilai agama Islam. Pandangan Islam terhadap metodologi Barat, mereka (kaum Barat) menafikan wahyu dan intuisi sebagai sumber ilmu. Dari pemaparan beliau jelas terlihat bahwa sumber ilmu dari Barat jauh dari nilai-niai ajaran Islam dan lebih menitikberatkan kepada ilmu yang lebih bersipat logis, empiris, dan terukur. Hal ini ketika di terapkan dalam pendidikan Islam jelas akan kehilangan ruh spiritual yang di kembangkan di negara Indonesia, yang berpedoman kepada wahyu yang memandu ilmu.

Sumber ilmu itu hanya ada dua macam, yaitu akal dan pengalaman manusia. Bagi mereka yang menganut paham rasionalisme, ilmu itu bersumber dari akalnya. Bagi mereka yang menganut paham empirisme, ilmu itu bersumber dari pengalaman. Dari sisi orientasi, Islam memahami bahwa ilmu itu akan mengantarkan manusia kepada pengakuan akan kebesaran Tuhannya, pengakuan akan adanya Yang Mahabesar di antara yang besar, pengakuan bahwa tidak ada yang berhak (benar) disembah melainkan Dia, tidak ada yang pantas ditakuti kecuali Dia. Jadi, muara ilmu itu adalah pengakuan akan eksistensi Tuhan, yaitu Allah Swt. 


\section{AL- ADABIYAH: Jurnal Pendidikan Agama Islam}

Di samping itu, semakin banyak ilmu seseorang, maka akan bertambah rasa takutnya kepada Sang Pencipta. Bukan malah bertambah angkuh dan sombong, tetapi dengan ilmu ia semakin mengenal Tuhannya dan bertambah ketakutan kepada-Nya. Berbeda dengan barat, dalam konsep mereka, ilmu itu tidak bermuara kepada Tuhan, karena mereka tidak mengakui adanya wahyu sebagai sumber ilmu, maka ilmu yang mereka miliki itu tidak akan membawanya kepada kebenaran. Dengan ilmunya dia akan sombong dan rakus karena metodologi barat mengajarkan untuk menyakini segala sesuatu itu berwujud (materialisme).

Arie Rakhmat Riyadi (2020) selaku dosen Universitas Pendidikan Indonesia, Fakultas Ilmu Pendidikan, Prodi PGSD menyatakan bahwa:

Ketidakpahaman masyarakat dan guru itu sendiri yang menganggap keberhasilan belajar hanya dillihat dari aspek kognitif, tidak memperhatikan perilakunya yang buruk, dan hal ini kurang sesuai dengan tahap perkembangan anak yang seharusnya lebih menekankan pada nilai afektif atau sikap.

Masyarakat cenderung cemas jika nilai anaknya rendah daripada perilakunya yang buruk, misalnya masyarakat cenderung akan membangunkan anaknya untuk bersiap-siap pergi ke sekolah daripada untuk beribadah (shalat). Selanjutnya Tatang Syarifudin (2020) selaku dosen Universitas Pendidikan Indonesia, Fakultas Ilmu Pendidikan, Prodi PGSD menyatakan bahwa:

Bisa saja metode barat itu baik untuk digunakan sebagai alat pembantu dalam pembelajaran untuk mengembangkan potensi siswa, namun kita harus menentukan isi dengan tepat agar tercapai apa yang diharapkan. Metode barat dan metode Islam pada pendidikan dasar tidak jauh berbeda, sama-sama ada ceramah, diskusi, pembelajaran individual (sorogan), dan yang berdasarkan pengalaman, hanya barangkali masyarakat dan guru kurang mempelajari metode-metode dari Islam itu sendiri. Barat maupun Islam sama-sama melihat atau berlandaskan kepada tahap perkembangan anak, bahkan Islam sudah lebih ada dan terperinci. Contoh ketika masa kehamilan, biasanya muslimah mendengarkan murottal Al-Qur'an atau berselawat (shalawat) sedangkan yang non-Islam atau orang barat mendengarkan musik klasik atau jaz. Jadi, ada kesamaan cara namun berbeda isinya. Dalam pemilihan metode (bisa dari mana saja) harus disertai dengan penentuan tujuan dan isi pembelarajan serta melihat tingkat perkembangan siswa. Penerapan metode akan berhasil tergatung siapa atau guru yang mengajarkannya.

\section{Perbedaan Konseptual Pendidikan Barat dan Islam}

Secara konseptual kedua entitas peradaban barat dan Islam memiliki cara pandang dan tekanan pemahaman yang sangat berbeda terhadap masalah 


\section{AL- ADABIYAH: Jurnal Pendidikan Agama Islam}

pendidikan. Perbedaan itu bisa saja karena perbedaan sistem penalaran masingmasing oleh konteks sosio-kultural yang melingkupinya.

Hakikat pendidikan barat selain hanya dibatasi pada ranah dhahir, pendidikan barat juga hanya berorientasi pada kedewasaan dunia dan mengesampingkan akhirat. Peserta didik hanya diajak berpikir secara sadar pada objek-objek yang bersifat material-positivistik. Pemahaman ontologis yang demikian akan mengantarkan arah dan tujuan pendidikan mereka yang sangat sekuler. Urusan moral, etika dan, agama bagi mereka tidak dikait-kaitkan dengan kehidupan publik.

Sementara itu, metodologi pendidikan Islam tidaklah demikian. Metodologi pendidikan dalam Islam adalah pendidikan yang mutlak berdasarkan pada paradigma sistem nilai-nilai keagamaan, etika, dan moral. Pendidikan apa pun coraknya, termasuk pendidikan umum, selalu saja sarat dengan basic (dasar) nilai. Model pendidikan yang di dalamnya sengaja ditanamkan nilai-nilai al-akhlaq dan alkarimah. Oleh karena itu, konsepsi pendidikan Islam menurut Nurhayati (2019:120) adalah konsepsi pendidikan yang menyentuh dua domain sekaligus, yaitu domain fisik maupun psikis, dhahir maupun batin, jasmani maupun rohani, sebagai tujuan pendidikan nasional kita. Pendidikan Islam harus mengembangkan seluruh aspek kehidupan manusia, baik spiritual, intelektual, imajinasi (fantasi), jasmaniah, keilmiahannya, bahasanya, baik secara individual maupun kelompok, serta mendorong aspek-aspek itu ke arah yang lebih baik (Mudhofar, 2019).

Objek kajian pendidikan Islam senantiasa bersumber dari landasan normatif Islam yaitu al-Qur'an (qauliyah) melalui pengalaman batin Nabi Muhammad SAW yang kemudian kita kenal dengan wahyu, kemudian disampaikan kepada seluruh umat dan alam semesta (kauniyah). Dari kedua landasan inilah kemudian digali dan dikaji sehingga melahirkan konsep dan teori pendidikan yang bersifat universal. Kemudian, teori dan konsep yang bersifat universal tersebut dikaji melalui kegiatan eksprimen dan penelitian ilmiah yang pada gilirannya akan melahirkan teori-teori atau Ilmu Pendidikan Islam dan diuraikan secara operasional untuk kemudian dikembangkan menjadi metode, kurikulum dan teknik pendidikan Islam.

Hal ini sejalan dengan tujuan pendidikan dan pengajaran Islam, yakni menjadikan seluruh manusia sebagai hamba Allah Swt. Tujuan ini sesuai dengan tujuan diciptakannya manusia, yaitu mengembangkan pikiran manusia, mengatur tingkah laku, dan perasaannya berdasarkan Islam (T. Hidayat dkk., 2018). 


\section{AL- ADABIYAH: Jurnal Pendidikan Agama Islam}

Pendidikan yang baik seharusnya dirancang untuk menghubungkan pengetahuan dan tindakan. Pendidikan juga mengisyaratkan tujuan-tujuan tertentu berupa keterampilan dasar, sifat-sifat pribadi, serta kemampuan interpersonal. Dengan demikian, kegiatan-kegiatan belajar mengajar lebih bermakna (Parhan, 2018).

Sejatinya kita menginginkan peserta didik secara aktif mengembangkan potensi dirinya untuk memiliki kekuatan spiritual keagamaan, pengendalian diri, kepribadian, kecerdasan, akhlak mulia, serta keterampilan yang diperlukan dirinya, masyarakat, bangsa dan negara (UU RI No. 20 Tahun 2003).

Selain hal yang telah dibahas di atas, mahasiswa yang menempuh pendidikan memercayai teori dan tokoh yang membawanya secara buta dan menelan mentahmentah teori-teori tersebut tanpa mengkritisinya, seperti halnya seorang tokoh yang membahas tentang tahap perkembangan moral ialah L. Kohlberg yang terbukti memperluas teori kognitif Piaget. L. Kohlberg dinyatakan bunuh diri karena depresi atas penyakit yang dideritanya. Ini adalah salah satu hal yang menunjukkan kelemahan pendidikan barat, berbeda dengan Nabi Muhammad saw. yang sudah jelas baik akhlaknya dan bahkan diakui dunia sebagai manusia terbaik no.1 (Michle Heart, 1978).

\section{Pengertian Metode dan Metodologi}

Dari segi bahasa, "metode" berasal dari dua kata, yaitu meta dan hodos. Meta berarti "melalui" dan hodos berarti "jalan" atau "cara". Dengan demikian dari sudut pandang ini, maka metode dapat dimaknai sebagai jalan atau cara yang harus dilalui untuk mencapai suatu tujuan. Dalam bahasa Arab metode diungkapkan dalam berbagai kata terkadang digunakan dalam kata Al-Thariqah, Manhaj, dan Al-Wasilah yang berarti perantara atau mediator. Dengan demikian kata Arab yang dekat dengan arti metode adalah Al-Thariqah.

Sebagaimana yang dikutip oleh Muhammad Noor Syam (dalam Rianie, 2015) secara teknis menerangkan bahwa metode adalah: (1) suatu prosedur yang dipakai untuk mencapai suatu tujuan, (2) suatu teknik mengetahui yang dipakai dalam proses mencari ilmu pengetahuan dari suatu materi tertentu, dan (3) suatu ilmu yang merumuskan aturan-aturan dari suatu prosedur. 


\section{AL- ADABIYAH: Jurnal Pendidikan Agama Islam}

Dari beberapa pengertian di atas, maka dapat disimpulkan bahwa meode adalah teknik atau cara teratur untuk mencapai tujuan yang diharapkan dalam proses mencari ilmu.

Berdasarkan pengertian di atas maka dapat disimpulkan bahwa metodologi adalah ilmu yang mempelajari cara atau jalan yang digunakan untuk mendidik agar mencapai tujuan yang diharapkan. Metodologi pendidikan adalah suatu ilmu pengetahuan tentang cara yang dipergunakan dalam mendidik siswa (Arifin, 2008).

\section{Jenis Metode Pendidikan Barat}

Adapun jenis metode pendidikan barat sebagai berikut.

1. Dialektika versi idealisme, Plato memandang bahwa kebaikan adalah hakikat tertinggi dalam mencari kebenaran, namun kebenaran yang datang dari manusia tidak selalu benar, pola pikir manusia berbeda sesuai stimulus yang diberikan selama hidupnya. Maka dari itu, pendidikan tidak bisa dilandasi oleh hal yang kebenarannya subjektif.

2. Metode logis, analitis, dan sesuai dengan psikologis adalah pendapat realisme dalam memandang kebenaran berikut dalam metode pendidikan. Kebenaran terlihat bila bisa diobservasi dan dianalisis, namun ada hal di dunia ini yang tidak mampu diteliti oleh indra manusia. Maka dari itu, bila pendidikan dilandasi dengan pengaruh filsafat ini hanya akan menjadikan peserta didik sebagai manusia penuh ambisi, yang selalu berusaha menghilangkan kehausan akan keingintahuan mereka.

Adapun dalam Mudyaharjo (2009), aliran pendidikan Pestalozzianisme, dengan tokohnya Pestalozzi, ada beberapa metode pendidikan yang digunakan, yaitu: (1) pendidikan adalah perkembangan yang harmonis antara akal (intelektual), hati (moral), dan tangan (keterampilan), (2) pendidikan umum mendahului pendidikan keterampilan, (3) pendidikan lebih mengutamakan kemampuan dari penguasaan pengetahuan, (4) pendidikan anak muncul dari dalam diri, (5) pendidikan berlangsung secara bertahap sesuai dengan tahap-tahap perkembangan, dan (6) pendidikan mengikuti tatanan alam (the road of nature).

\section{Tahapan dan Jenis Metode Pendidikan Menurut Islam}




\section{AL- ADABIYAH: Jurnal Pendidikan Agama Islam}

Rasulullah saw. dalam mengajarkan pengetahuan dan mendidik umat ternyata juga mempertimbangkan aspek perkembangan psikologi umatnya. Rasulullah saw. dalam menyampaikan penjelasan wahyu dari Allah Swt. disesuaikan dengan taraf berpikir umatnya. Oleh karena itu, dalam menjelaskan sebuah masalah Rasulullah saw. tidak menyamaratakan antara sahabat yang satu dengan sahabat lainnya, terutama kepada kaum Arab Badui yang notabene pola berpikirnya masih primitif (M. Samsudin, 2015). Sehingga terdapat tahap dan jenis metode pendidikan menurut Islam, antara lain sebagai berikut.

1. Belajar Mendengar dengan Metode Kisah dan Nasihat

Belajar mendengar adalah hal yang terpenting dan dasar bagi anak karena sejak lahir organ yang yang berfungsi pertama kali adalah indra pendengaran. Anak shaleh mendengar setiap perintah ibunya, sedangkan anak tidak shaleh tidak mendengar setiap perintah ibunya. Pendengaran merupakan indra terpenting di dalam kehidupan manusia.

Dalam Islam terdapat metode pendidikan melalui istima' (pendengaran). Nabi Muhammad saw. selain fasih dalam berbicara, beliau memiliki telinga yang tajam dan fokus yang kuat (Gustini, 2019).

Mendidik anak melalui kegiatan mendengar adalah pendidikan yang seharusnya ditanamkan sejak awal sebelum menempuh pendidikan lainnya. Dampak dari diperdengarkan Al-Qur'an sejak di dalam kandungan dan diajarkan hafalan Al-Qur'an sebelum membaca kepada anak antara lain:

a. Anak akan mendengarkan setiap perintah dan larangan-Nya.

b. Anak akan berkonsentrasi di sekolah.

c. Anak memiliki otak yang lebih cerdas daripada yang tidak.

Metode mendengarkan yang perlu disampaikan kepada anak dalam Islam adalah metode kisah, metode yang menampilkan cerita secara faktual tentang kehidupan manusia yang dimaksudkan agar kehidupan manusia bisa seperti pelaku yang ditampilkan oleh kisah-kisah yang terdapat di dalam sumber pendidikan Islam itu sendiri. Ramayulis (dalam Harahap, 2018, hlm. 16) mengartikan metode kisah adalah suatu cara mengajar di mana guru memberikan materi pembelajan melalui kisah atau cerita. Menurut Shaleh (dalam Harahap, 2018, hlm. 16) salah satu contoh kisah di dalam Al-Qur'an yang bisa disampaikan kepada anak ialah kisah Nabi Musa a.s. dengan Raja Fir'aun, kisah ini mengandung beberapa contoh perbuatan baik yang dilakukan oleh Nabi Musa a.s. dan contoh perbuatan buruk yang dilakukan oleh Raja Fir'aun. 


\section{AL- ADABIYAH: Jurnal Pendidikan Agama Islam}

Selain metode kisah, anak-anak atau peserta didik dapat diberikan nasihat dengan waktu yang tepat, Al-Qur'an juga menggunakan kalimat-kalimat yang menyentuh hati untuk mengarahkan manusia kepada ide yang dikehendakinya. Inilah yang kemudian dikenal dengan nasihat. Dalam mewujudkan interaksi antara pendidik dengan peserta didik, nasihat merupakan cara mendidik yang bertumpu pada bahasa. Cara ini banyak sekali dijumpai dalam Al-Qur'an, karena nasihat pada dasarnya bersifat penyampaian pesan dari sumbernya kepada pihak yang dipandang memerlukannya.

\section{Belajar Melihat dengan Metode Teladan}

Belajar melihat adalah dasar dalam pembelajaran bagi anak. Seperti halnya melihat warna-warna yang akan mengubah suasana hati anak (Gustini, 2019). Salah dalam melihat dapat memengaruhi cara berpikir dan berbicara. Maka dari itu, anak harus diperkenalkan sejak berada di kandungan, seorang ibu perlu mendengar dan melihat yang baik saja agar bayinya terlatih untuk mendengar dan melihat yang baik juga. Setelah bayi lahir seorang ibu hendaknya memperlihatkan gambar-gambar yang berkaitan dengan Al-Qur'an agar tersimulasi dengan kebaikan. Saat anak meginjak 2 tahun, orang tua harus membatasi melihat tayangan televisi yang akan menyebabkan anak menjadi stres dan pemarah. Membersihkan rumah adalah salah satu dari menjaga pandangan (Gustini, 2019).

Maka dari itu, metode yang cocok sembari menstimulasi mata dengan kebaikan adalah metode pengajaran teladan. Dalam Al-Qur'an, kata "teladan" diproyeksikan dengan kata "uswah" yang kemudian diberi sifat di belakangnya seperti sifat hasanah yang berarti baik. Sehingga terdapat ungkapan uswatunhasanah yang artinya teladan yang baik. Suatu hal yang tidak dapat dipungkiri bahwa anak-anak cendrung suka dan senang meniru tingkah laku orang tua, guru atau pendidik, serta orang lain yang dikaguminya.

Kata "uswah" dalam Al-Qur'an diulang sebanyak 6 kali dengan mengambil sampel pada diri para Nabi, yaitu Nabi Muhammad saw., Nabi Ibrahim, dan kaum yang beriman teguh kepada Allah Swt. Salah satu ayat yang menyinggung tentang uswah adalah QS. Al-Ahzab (33): 21, yang artinya:

"Sungguh, telah ada pada (diri) Rasulullah itu suri teladan yang baik bagimu (yaitu) bagi orang yang mengharapkan (rahmat) Allah dan (kedatangan) hari Kiamat dan yang banyak mengingat Allah" 


\section{AL- ADABIYAH: Jurnal Pendidikan Agama Islam}

Jelas terlihat bahwa metode dengan keteladanan yang baik dan berbudi pekerti yang agung yang di implementasikan dalam kehidupan sehari-hari, ini sangat efektif ketika diaplikasikan di dalam dunia pendidikan dan pengajaran. Sebab ajaran Islam yang dibawah oleh para Nabi dan Rasul mengandung arti, petunjuk hidup yang telah ditetapkan oleh Allah untuk manusia, yang disampaikan dan dicontohkan oleh para utusannya, guna mencapai kebahagiaan didunia dan akhirat kelak.

\section{Belajar Berpikir}

Berpikir berasal dari kata "pemikiran", secara etimologis pemikiran berasal dari kata dasar "pikir" yang berarti proses, cara, atau perbuatan memikir, yaitu menggunakan akal budi untuk memutuskan suatu persoalan dengan memperhatikan segala sesuatu secara bijaksana (Yuliani, 2018, hlm. 2). Belajar berpikir adalah suatu dasar yang terpenting bagi anak. Oleh karena itu, berpikir adalah pembelajaran ke-3 setelah mendengar dan melihat.

Agama Islam sangat memetingkan stimulasi otak dalam setiap aspeknya (Gustini, 2019) seperti halnya berikut ini.

a. Bahasa Arab adalah bahasa otak yang dapat menstimulus otak kiri dan kanan.

b. Mengatur pergantian anggota badan kiri dan kanan yang digunakan dalam kehidupan sehari-hari agar otak kita selalu berpikir.

c. Allah Swt. memerintahkan manusia untuk berpikir dengan menggunakan perkataan aqala-ya'qilu (berakal), fakara-yafkiruj (berpikir), dan ululalbab (orang-orang yang memiliki akal sehat).

d. Banyak yang masuk neraka karena tidak berpikir.

e. Orang kafir adalah orang yang tidak berakal atau tidak berpikir.

f. Mendengarkan Al-Qur'an adalah melindungi otak reptile dari berpikir liar.

g. Azan diperdengarkan 5 kali sehari untuk melindungi jiwa dan otak dari pikiran jahat maupun bisikan setan.

h. Shalat menjaga kesucian jiwa, hati, dan otak dari perbuatan jahat dan munkar.

4. Belajar Berbicara dengan Metode Diskusi

Belajar berbicara adalah dasar pembelajaran terpenting bagi anak. Banyaknya masalah terjadi karena salahnya berbicara. Banyaknya pertengkaran karena perkataan yang tidak dipikir sebelum diucap. Oleh karena itu, mulut atau 


\section{AL- ADABIYAH: Jurnal Pendidikan Agama Islam}

lidah adalah salah satu pelajaran terpenting. Banyak ayat-ayat Al-Qur'an dan Hadits yang mengandung tentang pentingnya berbicara (Gustini, 2019), di antaranya:

a. Ada lebih dari 200 kata "qul" (katakanlah oleh kamu) di dalam Al-Qur'an.

b. Dilarang mengatakan perkataan yang tidak baik.

c. Perintah mengatakan kebaikan walaupun pahit.

d. Orang yang beriman pada hari akhir akan berkata baik.

e. Orang muslim yang menjaga lidahnya lebih utama daripada yang tidak.

f. Neraka bagi yang tidak menjaga mulutnya.

g. Setiap ucapan akan dihisab.

Sejalan dengan belajar berbicara, bisa langsung dipraktikkan dengan metode mengajar diskusi. Metode ini diperhatikan oleh Al-Qur'an dalam hal mendidik dan mengajar manusia dengan tujuan lebih memantapkan pengertian, sikap, dan pengetahuan mereka terhadap suatu masalah.

Metode diskusi adalah suatu cara penyajian atau penyampaian beban pelajaran di mana pendidik memberikan kesempatan kepada peserta didik untuk membicarakan dan menganalisis secara ilmiah guna mengumpulkan pendapat, membuat kesimpulan atau menyusun alternatif pemecahan suatu masalah (Ramayulis, 2008, hlm. 194).

Selanjutnya dapat dibiasakan dengan metode yang berdiri sendiri seperti berikut.

a. Metode Pembiasaan

Cara lain yang digunakan Al-Qur'an dalam memberikan materi pendidikan adalah melalui kebiasaan yang dilakukan secara bertahap. Dalam hal ini termasuk mengubah kebiasaan-kebiasaan negatif.

b. Metode Hukuman dan Ganjaran

Terhadap metode hukuman tersebut terdapat pro dan kontra, setuju dan menolak. Kecenderungan-kecenderungan pendidikan modern sekarang memandang tabu terhadap itu, padahal dalam kenyataannya, manusia banyak melakukan pelanggaran dan ini tidak dapat dibiarkan. Islam memandang bahwa hukuman bukan sebagai tindakan yang pertama kali yang harus dilakukan oleh seorang pendidik dan bukan pula cara yang didahulukan. Nasihatlah yang paling didahulukan. Di dalam Al-Qur'an hukuman biasa dikenal dengan nama "azab” yang di dalamnya diulang sebanyak 373 kali. Jumlah yang besar ini menunjukkan perhatian yang amat besar terhadap masalah hukum ini dan meminta perhatian dari 


\section{AL- ADABIYAH: Jurnal Pendidikan Agama Islam}

umat manusia. Sedangkan kata ganjaran disebut dengan kata "ajrun" yang diulang dalam Al-Qur'an sebanyak 105 kali (Gustini, 2019).

\section{KESIMPULAN}

Metodologi adalah keseluruhan dari bahasan pendidikan yang kita pelajari, di mana pendidikan dipengaruhi oleh landasan, sejarah perjuangan, dan agama. Indonesia sebagai negara yang berlandaskan Pancasila, di mana cita-cita pendidikan yang penuh dengan keinginan menjadikan masyarakatnya tidak hanya cerdas namun juga beriman dan bertakwa kepada Tuhan Yang Maha Esa. Penerapan metodologi barat pada pendidikan dasar di Indonesia menurut pandangan Islam masih terdapat beberapa problematika, yaitu: (1) dalam hal mendidik, metodologi barat menggunakan teori psikologi dari barat yang mengibaratkan perilaku hewan seolah-olah seperti perilaku manusia. Padahal hewan tidak bisa disamakan dengan manusia, dikarenakan manusia diberikan akal oleh Tuhan, (2) terdapat tahapan mendidik anak yang hilang sehingga hak seorang anak tidak terpenuhi secara utuh, (3) tidak mengaitkan dengan tuhan dan mengesampingkan akhirat (sekuler).

Hal ini dapat diatasi dengan menerapkan beberapa cara mendidik anak yang dicontohkan oleh Rasulullah saw., yaitu kembalikan kepada Al-Qur'an dan Hadits. Namun bukan berarti penerapan metodologi barat itu tidak perlu dipelajari dan dikubur layaknya hal yang buruk, boleh diterapkan namun tidak bisa diterima utuh tanpa adanya penyelidikan dan penyaringan.

\section{REFERENSI}

Arifin. (2008). Imu Pendidikan Islam. Jakarta: PT Bumi Aksara.

Burhaein, E. (2017). Aktivitas Fisik Olahraga untuk Pertumbuhan dan Perkembangan Siswa SD. Indonesian Journal of Primary Education Vol. 1 No. 1.

Gustini, Nia. (2019). Metodologi Pendidikan Islam yang Diterapkan Barat dalam Pendidikan Dasar. Bandung: Referensiana Pustaka. 


\section{AL- ADABIYAH: Jurnal Pendidikan Agama Islam}

Harahap, Ahmad S. (2018). Metode Pendidikan Islam dalam Perspektif Filsafat Pendidikan Islam. Jurnal Hikmah Vol. 15 No. 1, 16. ISSN: 1829-8419.

Heart, Michael. (1978). The 100: A Ranking of the Most Influential Persons in History. New York: Hart Publishing Company Inc.

Hidayat, T. dkk. (2018). Pendidikan dalam Perspektif Islam dan Peranannya dalam Membina Kepribadian Islami. Jurnal MUDARRISUNA Vol. 8 No. 2.

Ismail, F. (2018). Mengurai Problematika Pendidikan Indonesia (Upaya Menjawab Tantangan Zaman). Jurnal Ilmiah Iqra' Vol. 3 No. 2.

Mudhofar. (2019). Peran Filsafat terhadap Pendidikan Islam untuk Pembinaan Etika dalam Perspektif Islam. Jurnal Tinta Vol. 1 No. 1.

Mudyaharjo, Redja. (2009). Pengantar Pendidikan: Sebuah Studi Awal Tentang Dasar-Dasar Pendidikan pada Umumnya dan Pendidikan di Indonesia. Jakarta: Raja Grafindo Persada.

Nurhayati, I. (2019). Telaah Konseptual Pendidikan Barat dan Islam. TARBIYA ISLAMIA: Jurnal Pendidikan dan Keislaman Vol. 8 No. 1. ISSN: 118-133.

Parhan, Muhamad. (2018). Kontekstual Materi dalam Pembelajaran. Adi Widya: Jurnal Pendidikan Dasar Vol. 3 No. 1, 8-11. ISSN: 2527-5445.

Parhan, M. \& Sutedja, B. (2019). PENERAPAN PENDEKATAN PEMBELAJARAN KONTEKSTUAL DALAM PENDIDIKAN AGAMA ISLAM DI UNIVERSITAS PENDIDIKAN INDONESIA. Tarbawy, 6(2), 114-126. https://doi.org/10.17509/t.v6vi2.20165

Quran Surat Al-Ahzab (33) Ayat 21.

Ramayulis. (2008). Ilmu Pendidikan Islam. Jakarta: Kalam Mulia.

Rasyidin, dkk. (2017). Landasan Pendidikan. Bandung: Universitas Indonesia.

Rianie, N. (2015). Pendekatan dan Metode Pendidikan Islam. Management of Education Vol. 1, 105-118.

Samsudin, M. (2015). Pendidikan Anak Perspektif Islam dan Barat. Jurnal Pendidikan Universitas Garut Vol. 09 No. 01, 36. ISSN: 1907-932X

Suyitno, Y (2020)., Arie Rakhmat Riyadi (2020)., dan Tatang Syarifudin (2020) merupakan Dosen Universitas Pendidikan Indonesia di Fakultas Ilmu Pendidikan prodi PGSD

Undang-Undang Nomor 20 Tahun 2003 Tentang Sistem Pendidikan Nasional Pasal 3. 
Wardi, Moh. (2013). Problematika Pendidikan Islam dan Solusi Alternatifnya. Tadrîs Vol. 08 No. 01

Yuliani. (2018). Konsep Pendidikan Islam dan Barat (Analisis Komparatif Pemikiran Imam Az-Zarnuji dan John Dewey). Rausyan Fikr Vol. 14 No. 2. ISSN: 